\title{
People living under threat of volcanic hazard in southern Iceland: vulnerability and risk perception
}

\author{
G. Jóhannesdóttir ${ }^{1, *}$ and G. Gísladóttir ${ }^{2}$ \\ ${ }^{1}$ Department of Geography and Tourism and Environmental Research Institute, University of Iceland, 101 Reykjavík, Iceland \\ ${ }^{2}$ Department of Geography and Tourism, Faculty of Life and Environmental Sciences, and Earth Science Institute, Askja, \\ University of Iceland, 101 Reykjavík, Iceland \\ * present address: The Icelandic Civil Protection, Skógarhlíð 14, 105 Reykjavík, Iceland
}

Received: 27 November 2008 - Revised: 7 January 2010 - Accepted: 18 January 2010 - Published: 26 February 2010

\begin{abstract}
Residents in the village of Vík and in the farming community of Álftaver in southern Iceland are living with the threat of volcanic hazards. The highly active subglacial volcano Katla has erupted approximately twice per century since the beginning of settlement around $874 \mathrm{AD}$. The last major eruption was in 1918 and Katla has recently entered an agitated stage. The purpose of this research was to (1) review residents' responses in relation to vulnerability, (2) examine their risk perception, preparedness and mitigation in relation to an eruption of Katla, and (3) investigate the public and the representative of the local authorities and emergency manager's knowledge of the official evacuation plan. In 2004, we conducted in-depth, face-to-face interviews with local residents using a snowball sample technique. All participants were permanent residents of the two communities, between the ages of 25-95 and most had lived in the area their entire lives. Regardless of the residents' knowledge about past volcanic activity of Katla and the associated future risk, many residents were doubtful about the imminent eruption forecast by scientists and they believed that the volcano is no longer active. In both communities, different social, cultural and economic factors played a central role in how people perceived natural hazards and how they dealt with the fact that their lives and livelihoods could be at risk. The participants had good knowledge about the existing evacuation plan and had participated in evacuation exercises. However, they had not made personal mitigation or preparedness plans in the event of a future eruption. In contrast to the residents of Vík, the inhabitants in Álftaver are concerned about the evacuation process and found it very confusing; they neither found the emergency plan nor the proposed methods for risk communication relevant for their farming community. The per-
\end{abstract}

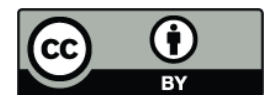

Correspondence to: G. Jóhannesdóttir (gudrunj@rls.is) ception of the inhabitants, especially in Álftaver, does not correspond to those tasked with the responsibility of developing the emergency and evacuation plans. In order to ensure the safety of all concerned, better cooperation, mutual understanding and adequate communication between the scientific community, governmental and local authorities and the inhabitants is necessary.

\section{Introduction}

Iceland has a rich heritage of documenting events in the country ever since the beginning of settlement in $874 \mathrm{AD}$. Through this documentation, volcanic eruptions, earthquakes, snow avalanches and other natural events can be investigated to some extent. Many of the catastrophic natural hazard events that have occurred in the country are described in detail. Eruptions in the sub-glacial volcano of Katla are one of such a catastrophic event type (Safn til sögu Íslands, 1907-1915).

Settlements to the south and east of Mýrdalsjökull have been threatened by the Katla volcano since the early settlement of Iceland in the 9th century. The volcano is highly active (Thordarson and Larsen, 2007) with 21 confirmed historic eruptions (Guðmundsson et al., 2008). Approximately 1-3 eruptions occur every century - the last one being in 1918 (Thordarson and Larsen, 2007). Katla, underlying the ice cap Mýrdalsjökull (Fig. 1), is one of the most hazardous volcanoes in Iceland (Björnsson, 2002) due to the sudden meltwater floods, called jökulhlaup, that surge from the glacier during an eruption. Catastrophic jökulhlaup have flooded the Mýrdalssandur area (Fig. 2). It has been suggested that the outburst floods, jökulhlaups, that emerged from Kötlujökull in 1955 and Sólheimajökull in 1999 were caused by small subglacial eruptions that did not break the

Published by Copernicus Publications on behalf of the European Geosciences Union. 

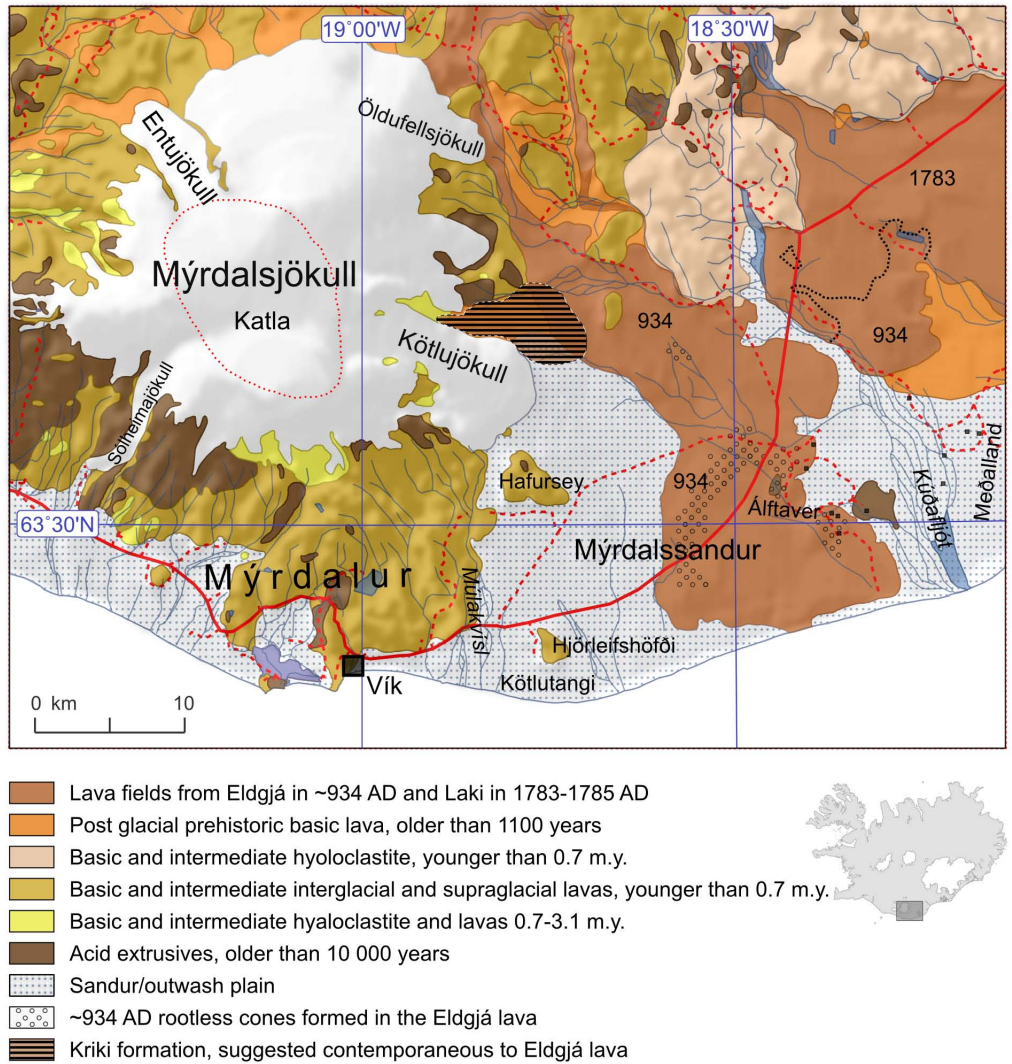

Fig. 1. The Volcano Katla and its surroundings. Historical jökulhlaups have emerged at Kötlujökull and Sólheimajökull and have formed the outwash plains in front of the glacier. Pre-historic jökulhlaup emerged at Entujökull. The historic Eldgjá lava and the rootless cones were formed during an eruption event (subaerial and subglacial) in the Katla volcanic system $\sim 934$ AD. Tephra covered the whole area shown on the figure, although being thickest east of Mýrdasljökull and the jökulhlaup emanated from the outlet glacier in the northeast, Öldufellsjökull. Repeated catastrophic jökulhlaups since 934 AD have formed the Mýrdalsandur outwash plain. Outlines of Eldgjá lavas are from Larsen (2000), the Katla caldera by Björnsson et al. (2000) and other geological phenomena by Jóhannesson et al. (1990).

ice surface (Guðmundsson et al., 2007). The volcano is still highly active and has entered an agitated stage (Sturkell et al., 2006).

The natural hazards following the interaction of the Katla volcano and Mýrdalsjökull glacier are catastrophic jökulhlaup, tephra fallout, minor earthquakes, toxic gas and lightning. Eighteen of the documented Katla eruptions have been associated with jökulhlaup that have emerged from the eastern side of Mýrdalsjökull down to the Mýrdalssandur outwash plain (Fig. 2) and two from the southern side of Sólheimasandur. Katla eruptions are capable of breaking through the $400 \mathrm{~m}$ thick ice cover in 1-2 h (Björnsson, 2002) and floodwater emerges from the glacier $1-2 \mathrm{~h}$ after the onset of an eruption and flooding can reach settled areas soon after (Guðmundsson et al., 2005) (Fig. 3). Jökulhlaup are a mixture of water, ice blocks, volcanic products and a heavy load of sediment. In 1918, a jökulhlaup reached a peak discharge rate of $300000 \mathrm{~m}^{3} \mathrm{~s}^{-1}$ (Tómasson, 1996; Larsen, 2000; Björnsson 2002) (Fig. 2).
The flat agricultural and farming community of Álftaver (Fig. 2) is in the floodpath of jökulhlaup and is the community at greatest risk during a Katla eruption. The 1918 flood took the inhabitants by surprise as they had not felt any early warning signs (Bjarnason, 1986; Jóhannsson, 1919; Sveinsson, 1930), even though Katla jökulhlaups have been preceded by earthquakes $2-10 \mathrm{~h}$ before the floodwater emerged from the glacier (Safn til sögu Íslands, 1907-1915). Farmers who were gathering sheep on the Mýrdalssandur area in 1918 just escaped the flood and the inhabitants in Álftaver either stayed at farms located on hills or escaped to higher grounds (Bjarnason, 1986). According to the local population, (Jóhannesdóttir, 2005) the rootless cones (Figs. 1 and 4) to the west of the community have protected the farming society during eruptions.

Due to jökulhlaup and tephra, farms in Álftaver were desolated and regional agricultural land destroyed (Safn til sögu Íslands, 1907-1915, Gísladóttir, 1980; Gísladóttir and Margrétardóttir, 2004) (Fig. 2). The $0.5-1 \mathrm{~km}^{3}$ of tephra 

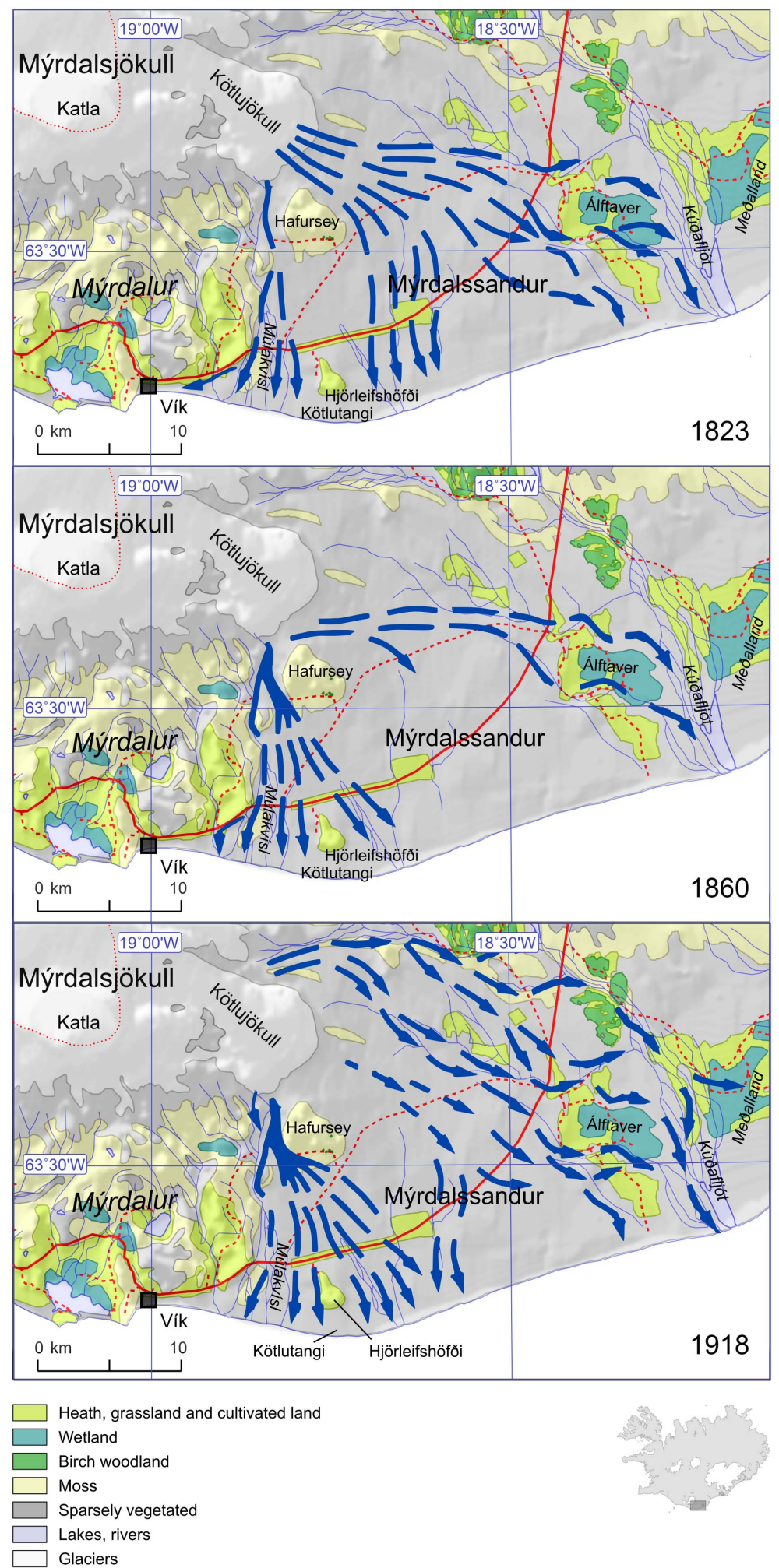

Fig. 2. The main paths of the three last major jökulhlaups across Mýrdalssandur. The repeated floods have destroyed vegetation in large areas on the sandur plain and have severely degraded vegetation and the farming area in Álftaver. Vegetation show present situation. Flood paths are from Larsen (2000), the Katla caldera by Björnsson et al. (2000) and the vegetation by Guðjónsson and Gíslason (1998). 

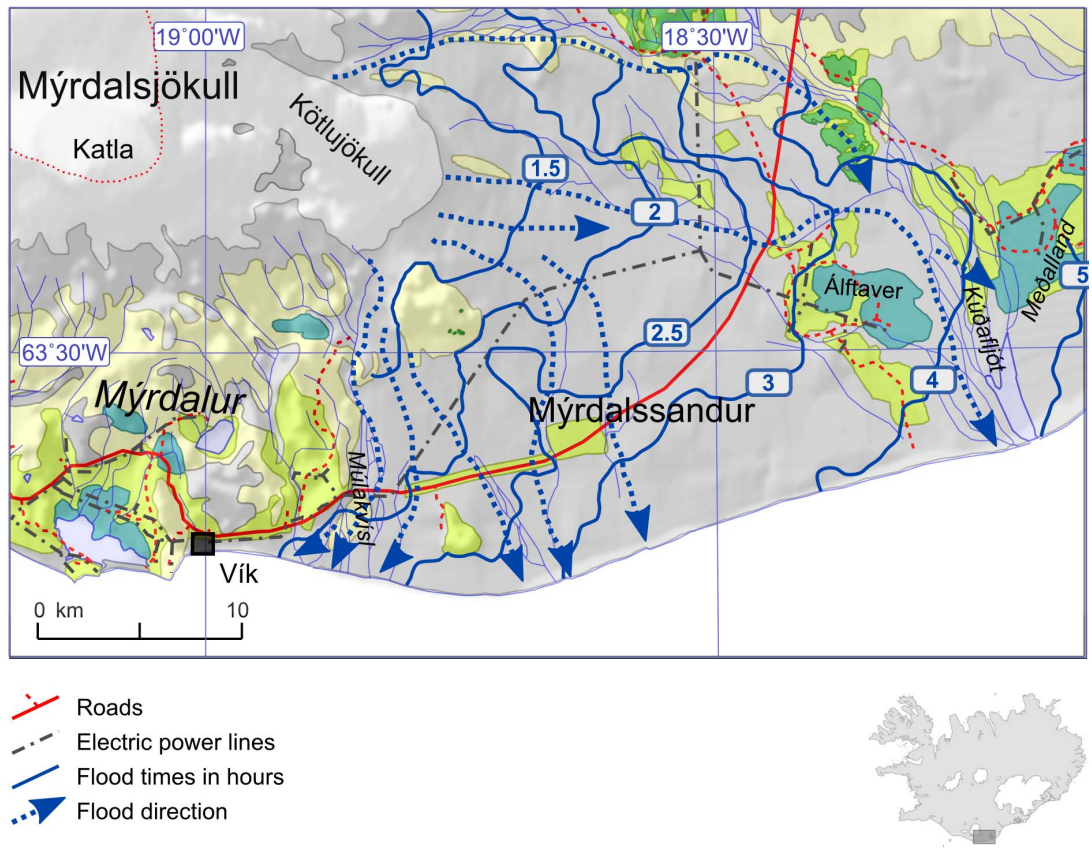

Fig. 3. The potential jökulhlaup hazard zone on Mýrdalssandur, estimated in 2005. Historically the flood emanated from Kötlujökull soon after the eruption broke through the ice cap. The time lines show the position of the flood after the eruption. It is estimated that within three hours the flood (of similar size as the jökulhlaup in 1918) will inundate the main highway, bridges and electric power lines and reach the settlement in Álftaver. As soon as the eruption is confirmed, residents in Álftaver and Vík need to evacuate, according to present evacuation plans. Vegetation classes are seen on Fig. 2. Time lines are after Ríkislögreglustjóri, Almannavarnadeild (2008) and the vegetation by Guðjónsson and Gíslason (1998).

and other debris carried by the jökulhlaup in 1918 elevated the surface of the outwash plain by $1 \mathrm{~m}$ (Thordarson and Hoskuldsson, 2002). Furthermore, the jökulhlaup in 1955 and the glacial rivers have raised the outwash plain (various residents, personal communication, 2003, 2004). Therefore, the rootless cones may not be as effective in protecting the local community. As a result of this combined effect, Álftaver may be more vulnerable to jökulhlaup hazard.

Katla eruptions have caused small tsunamis in Vík and in the Westman Islands about $60 \mathrm{~km}$ southwest of Vík (Safn til sögu Íslands, 1907-1915; Jóhannsson, 1918). In 1918 the jökulhlaup extended the coastline at Kötlutangi by $14 \mathrm{~km}^{2}$ (Figs. 1 and 3) (Thordarson and Hoskuldsson, 2002). Prior to 1918, coastal erosion was severe in Vík, but after this, the unconsolidated flood deposits forming Kötlutangi were carried by coastal currents to Vík causing continuous accretion until 1971. Since then, erosion has been prominent. At present, about $80 \%$ of the houses in Vík and the main highway are located on the beach close to the coastline (Ísaksson et al., 2005), making them more vulnerable to storm surges and tsunamis.

Given the descriptions of former eruptions of Katla (Safn til sögu Íslands, 1907-1915), the risk is substantial and it is likely to affect all aspects of residents' lives during and following an eruption. Furthermore, since the last eruption in 1918, the society has become a technologically advanced community and, therefore, the local community is more vulnerable since critical lifelines, transport and communication infrastructure, etc. are likely to be affected (Fig. 3).

The objective of the Icelandic Civil Protection (ICP) in Iceland since 1967 is to focus their attention on known natural hazards (Act No 94/1962) and the first emergency plans in Iceland were developed in 1972 for communities at risk. Snow avalanches, volcanic eruptions and earthquakes posed immediate threats to various districts, which needed emergency preparedness plans (Jónsson, 2003; Friðfinnsson, 2005). The local Civil Protection Committee and the district commissioner in Vík are in charge of local emergency preparedness and response and they work with the local municipal authorities in preparing the emergency plans in collaboration with the ICP (Act 94/1962). Emergency plans in Iceland are of two kind's, generic emergency plans that are used to respond to any major emergency and specific plans that deal with particular hazards, on specific locations or sites. Since the communities south and east of Katla are at great risk, a specific evacuation and response plan was prepared and exercised for a Katla eruption as early as 1973 (Fiðfinnsson, 2003). In 1999, the plans were revised and, since then, gradual changes were made in the plan that have not been exercised. Children in the town of Vík usually take part in an evacuation exercise every year at school, they are given detailed information where to go and what to do in an eruption, 


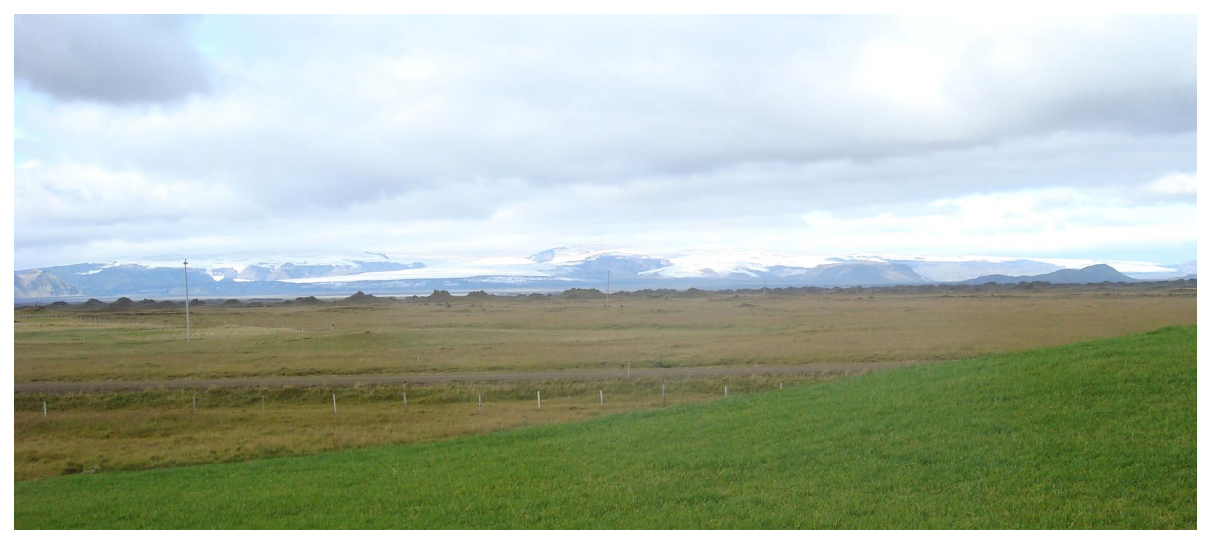

Fig. 4. Mýrdalsjökull seen from Álftaver with the row of rootless cones in the foreground. Photograph by Gísladóttir.

but other residents have to rely on exercises that have been few and far between. The plans were made by emergency managers in Vík and local and national administrators without involvement of the general public (Jóhannesdóttir, 2005). Recent findings (Kjartansson, 2008; Jóhannesdóttir, 2005; Bird et al., 2009) show that the approach of the Icelandic Civil Protection has generally been reactive to emergencies with less emphasis on prevention and preparedness. According to these findings, more effort has been expended in responding to various hazardous events than on prevention and education. Recently, however, public awareness on risk has been promoted by local and national civil protection authorities in various hazardous areas; for example by celebrating a Katla information day in the community of Vík in October, the day Katla started to erupt in 1918 and information brochures have been distributed to the inhabitants and tourists about the hazards following an eruption of Katla.

\section{Risk perception and vulnerability}

Risk is a product of the likelihood of an incident occurring and its possible consequences. It could be the suffering of harm or loss from a hazard that can cause injury, disease, economic loss or environmental damage. It is expressed in terms of probability - a mathematical statement about the probability of an occurrence (Miller, 1995).

When assessing probabilities, however, two main principles can be used (SEMA, 2008). Quantitative assessments, empirical estimates that constitute a recognized basis for assessment of probability, based on, for example, statistical material and qualitative assessments that are used to estimate probability, either to complement empirical data or as the sole relevant source. Probability is assessed based on the subjective estimates of persons with good knowledge of the pertinent conditions. Assessing consequences concerns anticipating the direct and indirect (negative) effects that can arise based on certain given condition (SEMA, 2008).
When looking at risk, three elements have to be considered: the hazard, the exposure and vulnerability. Chricton (1999) refers to these three elements as the risk triangle and if any one element increases or decreases then the related side of the triangle, area of the triangle and, hence, the amount of risk will increase or decrease accordingly. Involved in the concept of natural hazard, risk is an event, where actual or potential interaction between extreme natural events and human activities takes place which may impact on various elements that then become at risk and can make people vulnerable (Crichton, 1999; Alexander, 2000).

Vulnerability is the susceptibility to disturbances and losses, determined by exposure and sensitivity to disturbance, and the capacity to adapt (Smit and Wandel, 2006). The nature of perturbations (slow onset or sudden and episodic) and the location of the system in the risk cycle are crucial in shaping vulnerability.

More specifically natural hazard vulnerability generally refers to the characteristics of the element exposed to a hazard that contributes to its capacity to resist, cope with and recover from the impact of a natural hazard (Crichton, 1999). Elements at risk may be a population, their social structure and the built and natural environment that are likely to be affected by the hazard.

These elements can have both intrinsic and functional value and are often hard to calculate. With respect to communities, assessments relying only on numbers, statistics and objective calculation, may not necessarily give the same information as those based on the assessment of emotional and subjective information (e.g. Otway, 1992; Slovic, 2000, 2004). These qualitative assessments can provide an understanding of intangible social elements that influence daily lives. They can reveal factors that make people feel safe in their neighbourhood, indicate their tolerance, social cohesion and network, trust and expectations which indicate their vulnerability. Moreover, vulnerability measured by qualitative methods may explain how critically a society and its inhabitants will be affected by an event. How people 
perceive and look at risk depends on various factors: social (Fischoff et al., 1978; Slovic et al., 1978; Blaikie et al., 1994), psychological (Fischoff et al., 1978; Pidgeon et al., 1992; Blaikie et al., 1994), economic (Deyle et al., 1998), cultural (Sjöberg, 2000; Boholm, 1998) and environmental (Mileti, 1994; Haynes et al., 2008) or a combination of all factors (Alexander, 2000; Jóhannesdóttir, 2005). Furthermore, people are susceptible to damage and loss due to these factors. In this respect, risk perception can increase vulnerability and determine people's losses to a greater degree than the hazard itself. The meaning of risk may vary between people since actions and understanding about risks are learned by socially and culturally structured conceptions and evaluations (Alexander, 2000).

In cultural theory, risk perception is looked at as a reflection of the social context an individual finds oneself in and is not necessarily the sole determinant of risk perception (Sjöberg, 2000). In natural hazards, decisions on mitigation depend rather on how dangerous the risk is perceived rather than on absolute or objective conditions (Alexander, 2000). Normalization bias (Mileti, 1994; Gregg et al., 2004) and cognitive dissonance are terms that are sometimes used and refer to unrealistic behaviour, risk perception and denial of the existence of the hazard when people are living under threat. Others believe that disasters will happen to someone else (Alexander, 2000). Studies on risk perception have shown that most people have a much more comprehensive perception of risk than just probability and consequences (Kasperson et al., 1994). Consequently, risk perception is a function of beliefs and values and even specific fear (Sjöberg, 2000). The importance of events that are close in time and space tend to be magnified in the minds of people and those distant in time tend to diminish (Lindell, 1994). Both the scale and the accuracy of perception may depend on the extent to which lives and resources are at risk and on the context of social problems in the community (Alexander, 2000). It is more likely that policies are established with an emphasis on prevention and preparedness in an aftermath of disaster when risk perception is high and people are willing to adopt new measures. Analysing and evaluating social, cultural and psychological relations between vulnerability and risk perception helps to provide a better understanding of people's attitude towards risk and helps predict public response to hazard and risk (Mileti, 2000). This can be used to improve risk communication and risk reduction and associated conflicts during emergency situations (Gregg et al., 2004; Jóhannesdóttir, 2005; Bird and Dominey-Howes, 2006; Haynes et al., 2008; Bird et al., 2009, 2010).

Systematic identification and evaluation of threats, risk perception and vulnerabilities in communities can help prioritise suggestions for mitigation and increase resilience. An effective evacuation process is dependent upon the understanding of the official emergency planners and management officials of the potential public response to a disaster. If the risk perception of officials does not correspond to the pub- lic perception, a conflict is likely and vulnerability will not be reduced. To facilitate efficient risk communication, it is essential that earth scientists provide residents at risk with easily understood and accessible data (Alexander, 2007). In risk management, socio-economic, political and behavioural elements have to be taken into account along with the physical processes (Blaikie et al., 1994).

Therefore, the purpose of this paper is to investigate people's perception of natural hazards in two communities that have been exposed to volcanic hazard and to: (1) review residents' responses in relation to vulnerability, (2) examine their risk perception, preparedness and mitigation in relation to an eruption in Katla, and (3) investigate the public, local representative authorities and emergency managers' knowledge of the official evacuation plans.

\section{Methods}

The methodology used was in-depth, face-to-face interviews and a snowball sample technique (Balso et al., 1997). Snowball sampling involves, first, selecting persons who have characteristics that meet the requirement of the study and then asking them for further contacts. This method is often used to study a certain area or social groups. In this case, the topic is volcanic eruption and the geographical area is defined as a known hazard zone. The participants work and live close to the volcano and are familiar with the area. Therefore, their knowledge, beliefs and risk perception may give an indication to their vulnerability during an eruption and provide a basic understanding of the condition of people living under threat. Since disasters usually strike without much warning, most of the participants were visited in their home or workplace without prior warning. The reason was to determine the participants' knowledge, preparedness and response capabilities at a time when an eruption had been forecast by scientists. Furthermore, contact prior to interviewing was not made as we did not want the participants to prepare for the interview by reading the response and evacuations plans.

Additionally, it was essential to investigate the emergency management in the local community to evaluate the emergency procedure through the interpretation of the local emergency managers. Therefore, we interviewed the mayor and the district commissioner in Vík who are responsible for the prevention, preparedness and response to an emergency in the area, at the time of the research.

By using structured questionnaires and a quantitative interview technique, a much larger sample could have been obtained but it would not have given the knowledge of risk perception and vulnerability which met the purpose of the study. The size of the sample is not the major issue, since the results are not to be generalized for the whole population, but rather to get a basic understanding of risk perception and vulnerability in the two case study areas. In-depth interviews can facilitate the conversation about the respondents' 
experiences; they allow flexibility and they can produce rich invaluable information that only personal interviews provide (Balso et al., 1997). The results obtained by using this qualitative method, may provide emergency managers with useful information when preparing for emergencies. The participants' risk perception and vulnerability is investigated by using different socio-psychological, economic, environmental and cultural-historical factors in order to understand what makes the inhabitants vulnerable to natural hazard and, at the same time, to examine their knowledge of preparedness and evacuation plans.

All the interviews were conducted in October 2004. They were digitally recorded, then written down, organized, dissected and categorized for further analysis.

A semi-structured checklist was used in all the interviews in order to determine people's perception of risk and their vulnerability during Katla eruption. The discussions were open and the semi-structured checklist covered the following topics:

- The home, the family and friends. The participants were asked about their background; family, children, their extended family and friends and why they had chosen to live in this particular community. By delving into these relations and understanding the social structure, we hoped that we would understand their resilience or vulnerability.

- Work and economic status. In former eruptions the farmers lost livestock and land, therefore, it was important to understand how the participants saw their livelihood and sustenance in the future, with or without an eruption.

- Hazard and risk knowledge. Natural disasters are common in Iceland and recent events like snow avalanches, volcanic eruptions and earthquakes were considered compared to an eruption. This indicated their perception of risk from Katla.

- Katla emergencies. Oral tradition and historical knowledge about Katla from past generations may contribute to community resilience if they use this knowledge to their benefit. Therefore, information on these factors was considered valuable to study. If not mentioned, we asked residents if they believe an eruption was imminent. If so, had they made preparedness plans themselves to avoid risk including insurance?

- The environment. In relation to inherited knowledge about former eruptions, residents discussed what the impacts of an eruption could be on the environment. This included discussions about environmental degradation and their livelihood as well as the effect on the economy in the region.
- Response plans and evacuation exercises. Similarly, discussions about emergency response plans, their knowledge of the plans and the evacuation process. Involvement in evacuation exercises and training were also discussed.

- Scientists and research. We thought it important to gain an understanding about their perception and knowledge on scientific research on volcanoes in general and Katla specifically. We, therefore, asked if they had received research information on Katla, if the results were presented clearly and if they had trust in this information.

- The Civil Protection and emergency planning. Since trust can determine if residents will follow emergency advice during an eruption, we wanted to understand the residents' level of trust in the local Civil Protection Committee and the Icelandic Civil Protection, if they were satisfied with their work and had confidence in the authority's emergency planning.

\section{Results and discussion}

The sample size was 28 participants, male and females, all adults. In Álftaver there are 9 farms and 8 of them were visited and 11 participants were interviewed (Table 1). The participants in Álftaver lived in a closely connected community; all were farmers while one also worked in Vík. The area is isolated and their families had lived there for generations and the population is aging. In Vík, 17 out of the total population of 296 inhabitants were interviewed. The participants in Vík were in the service sector and some skilled workers. Each interview lasted for more that $2 \mathrm{~h}$.

The results are presented in a descriptive way according to the participants' response during the interview in October 2004 and are analysed and evaluated during the process (Balso et al., 1997). The focus is on the hazardous eruption of Katla and the consequent risk perception, vulnerability and emergency prevention and preparedness.

\subsection{Risk perception of Katla}

All participants knew about the volcano in the Mýrdalsjökull glacier and knew it had erupted regularly in the past. Their general knowledge was good and they knew about outburst floods in Álftaver and a potential tsunami in Vík. Nevertheless, they expressed their perception about the risk and consequences of an eruption in different ways. Most residents in Álftaver had first-hand knowledge from former residents in the area that had survived the outburst flood in 1918. They acquired their knowledge from their ancestors about the outburst flood in 1860, 1823 and so on.

In the beginning of the interviews, there seemed to be a lack of interest, apathy and silence about Katla and how the residents would cope with an eruption. Participants in the 
Table 1. The participants age distribution in Álftaver and Vík.

\begin{tabular}{lccccccc}
\hline $\begin{array}{l}\text { Age of } \\
\text { the participants }\end{array}$ & $\begin{array}{c}25-35 \\
\text { years }\end{array}$ & $\begin{array}{c}36-45 \\
\text { years }\end{array}$ & $\begin{array}{c}46-55 \\
\text { years }\end{array}$ & $\begin{array}{c}56-65 \\
\text { years }\end{array}$ & $\begin{array}{c}66-75 \\
\text { years }\end{array}$ & $\begin{array}{c}\text { 76 years } \\
\text { and older }\end{array}$ & Total \\
\hline Álftaver & & 3 & 1 & 2 & 2 & 3 & 11 \\
Vík & 2 & 3 & 2 & 5 & 2 & 3 & 17 \\
Total & 2 & 6 & 3 & 7 & 4 & 6 & 28 \\
\hline
\end{tabular}

farming area found it difficult to delve into the matter and did not answer directly. They rather referred to stories from former eruptions and what had saved the farmers. These accounts were of farmers riding on horses and heroic escapes from the outburst flood or the incredible rescue of livestock and people. Legends and mythology from the Middle Ages were frequently mentioned. In Vík, older participants, whose heritage originated in the local agricultural area, gave similar accounts.

Repeatedly mentioned were the legend of Krukkur and the legend of Katla. These stories and legends seemed to be their common cultural ties to the place.

The participants referred to a prophet from the Middle Ages called Krukkur. He had predicted that if the outburst flood from Katla would reach a certain place in Meðalland (Fig. 2), the eruption from Katla would cease and change its starting place and erupt at sea. The flood reached this place in 1918. In 1963 and 1973 two huge eruptions were out at sea not far from Katla close to and on the Westman Islands. Some residents who referred to Krukkur indicated that his predictions were valid and some even said they wanted to believe his predictions so Katla would not erupt again and harm them. These beliefs may have an impact on residents' level of preparedness and, therefore, it is important that emergency managers provide correct and up-to-date hazard information to the public in order to promote higher level of disaster awareness to reduce vulnerability.

When people in Álftaver and Vík refer to the volcano, they personify the image of Katla and always referred to it as a female Katla. This has its roots in a legend and old saga from the Middle Ages about a notorious female named Katla. She lived in the farming community of Álftaver and threw herself into a chasm in the Mýrdalsjökull glacier after a conflict with residents in the community. Soon after, there was an eruption in the glacier and it was seen as a revenge of Katla. In the affected communities, an eruption of Katla is always referred to as "The return of Katla", A woman referred to this legend when she said, "She (Katla) is up there, I am down here, she might return." Like an unwelcome guest, Katla is seen as someone who might return after an unpleasant visit in the past but the residents hope that she will stay away. By talking about the volcano in awe, their risk perception may increase their vulnerability, since they seem reluctant to deal with the situation.
When we asked about Katla, in the beginning of the interview, many of the participants said, "... we never talk about Katla! "She” (Katla) is not important, I don't think about an eruption; it's typically something people outside the community, outsiders worry about." "The media attention during minor earthquakes is tiresome and my relatives in the city become anxious and keep calling me and tell me to get out of there", a woman in Álftaver said. Nevertheless, later during the in-depth interviews many of the same participants revealed their concern about the hazard and risk which indicates the importance of this interview technique in such delicate matters. A woman in Álftaver described her thoughts as, "There is this feeling within when you think about the risk from an eruption, it is something you don't talk about as you make the kids scared and if you are scared all the time you just can't live here, so you just put these thoughts aside, more or less let the thought sleep while you try to live a normal life."

In Álftaver it was common that participants did not allow this imminent threat to take over their lives; they wanted to live a normal life so the threat was put aside, by normalizing the threatening situation as demonstrated by Mileti et al. (1992, 1994) and Gregg et al. (2004).

Older participants showed fear when talking about Katla and an older man told us he was shocked when he heard that his relatives had given their daughter the name Katla and he said, "to give a child this name is ridiculous!"

The consequences of an eruption are kept alive, especially within the farming community and detailed heroic stories about narrow escapes and bravery during an eruption have been passed on to the younger generation.

Scientific research and historical documentation show that eruptions from Katla have occurred during different months of the year (Larsen, 2000). Furthermore, scientific findings reveal that seismicity in the glacier around Katla has a distinct seasonal pattern with the majority of earthquakes occurring in the latter half of the year (Einarsson and Brandsdóttir, 2000). Even though earthquakes are a pre-warning to an eruption, the autumn seismicity is more likely to be related to (pore) pressure in the crust below the glacier and, to a minor degree, the reduced load of the glacier ice (Einarsson and Brandsdóttir, 2000). Many of the residents believed that, because of this seasonal pattern, an eruption was more likely to happen during autumn. One farmer even said, "If 
Katla would erupt again he hoped that it would be during autumn because it would be the most convenient time as the livestock is kept indoors during late autumn and winter and tourists are not hiking in the mountains at that time. People are not working in the fields and are, therefore, more likely to be at home." In this case, this scientific information has not reached all the participants.

Some residents have used their own cultural and historical explanations to minimize their fears (e.g. Sjöberg, 2000; Slovic, 2004; Mileti, 2000). For example, one woman in Álftaver stated, "There is always some activity in Katla during the autumn. She is like us women, we have our period every month but Katla has her motions every autumn but it does not necessarily mean an eruption. A woman in the village made the following comment about this seasonal seismicity, "Katla usually erupts during the autumn. There is always some unrest in the glacier at that time. It usually starts in August and the unrest is continuous throughout the autumn. Some melting will increase at that time and then at some point the glacier makes paths for the glacier's outburst flood."

Consequently this can make the residents more resilient during the autumn and more vulnerable at other times of the year, caused by the incoherence in objective research by scientists and subjective perceptions of the residents.

People in Álftaver perceived that other hazards in Iceland are riskier than an eruption from Katla, especially the recent disasters in the country like snow avalanches (1995) and earthquakes (2000). The risk was perceived in the number of deaths and destruction. In the snow avalanche disaster, many people died and in the earthquake the destruction of houses and properties was considerable. A common assumption was "I don't think people will die during an eruption." Fading memory of hazards and disaster distant in time is common (Lindell, 1994). Their risk perception is rooted in their value, fear, hazard and risk that they feel exposed to and it is assessed by reference to that experience (Slovic, 2004; Mileti, 2000)

The villagers in Vík perceived the hazard to be more of a threat to people in Álftaver than to themselves. One of the participants in Vík said, "I think of Álftaver as an awful place to live in when I think of the eruption, I believe the flood will have a severe impact on the farming community and destroy their livelihood. Later the tsunami will hit Vik but I don't think it will be more than a minor flood in some basements near the sea."

Similar comments were:

"The greatest hazard is in Álftaver, the area is so flat and the flood will force its way down there, I think here in Vik we will get the tsunami and we know what to do."

However, some perceived that the residents in Vík would be at risk. A woman in Vík whose parents experienced the last eruption in Katla was frightened when she talked about Katla eruption and believed that an eruption would be a catastrophic disaster, "... I fear the tephra fall, it will be horrific, and ash will keep you from getting away." The secondary effects from an eruption like ash and tephra fall were generally more strongly perceived in Álftaver than in Vík. This may be due to the fact that storytelling has a long tradition in the farming community and information about an eruption has been kept alive. Participants in Vík believed that the beach and the village would benefit from an eruption of Katla, since the unconsolidated sediment transported by the flood after the eruption in 1918 extended the beach. The residents in Vík saw this as a positive aspect of an eruption of Katla.

Another positive aspect was how people in both communities seemed to have strong cultural and historical attachment to their environment; they valued the landscape and nature and had strong social bonds. These things meant more to them than future hazards and risk (Hargreaves, 2004; Pidgeon et al., 1992). The locals especially valued raising children in rural communities because of perceived social security and safety. A woman in the village said, "indeed we are isolated here but if something happens to you or your family, there are always people here that care and will help you. I don't think that will happen in the city because often you don't even know your next door neighbour."

Again participants highlight and value the quality of the social relationship and community bonds. This perception may increase their resilience during an eruption.

A woman who had recently moved to the village was always thinking of an eruption reflected on her fear when she said, "But after a while you learn there is nothing to be afraid of and if something would happen there are people here that will take care of you." This shows that she learned to overlook the risk by trusting the locals and their experience since people living in a community with strong social relationship may support each other in crisis. She did not take action herself since she relied on others more experienced even though she lived so close to the hazard and knew about the consequences. By transferring the risk, she may be more vulnerable during an eruption (Gregg et al., 2004). Emergency managers must raise the residents' awareness in known hazardous areas by improving their capability to deal with hazardous events through education, training and exercise (Mileti, 2000).

\subsection{Vulnerability in the two communities}

First hand experience and perception of the risk is deeply embedded in the mind of an old lady. Even after 86 years from the Katla eruption, an indication about her vulnerability during an eruption is clear, "It was when I was a teenager, tephra and ash covered everything, there was lightning and thunder... I don't think anyone can believe the horror I experienced! This is something that I will never forget as long as I live. We were trying to work in the field the following summer but it was of no use, the ash covered everything."

Her worries represent the view Alexander (2000) expressed about society's tolerance levels, which tend to 
synchronize with the occurrence of the hazard. After a long inactive period, people tend to forget the horrendous consequences of a disaster and consequently hazard prevention and preparedness decreases.

For example, a woman in the village said, "I worry about the school that was built in 1976 so close to the coast ...I thought it was not safe, they never should have allowed development so close to the sea; it is too risky." Local planning authorities decided to build a school in an area by the sea. The local government planned land use in an area that could be exposed to risk. In emergency plans in Iceland schools are used as emergency aid centres during disasters and the local school was not considered safe enough during an eruption, therefore, another location was designated for this purpose up in the hills above the village.

In Álftaver people were concerned about their livelihood during and after an eruption and raised some economic and social questions related to vulnerability.

A farmer said, "We will be forced to evacuate and leave the livestock behind. We are not even allowed to milk our cows. It is obvious that the livestock will suffer and so will we. The government has to find a way to allow us to take care of our livestock during an eruption." In this respect, the farmer has both social and economic ties to his livelihood, making him even more vulnerable. Similar views were expressed by another farmer who said, "Our life is based on our land and I sometimes wonder what I will do if an eruption takes place and everything is taken away from me! Will it all be over?" Another farmer said, "what if the roads are blocked, no electricity, no phone connections, petrol and so on." His thoughts highlighted the social and economic changes in the communities since the last eruption in 1918 and the way modern societies depend on various critical infrastructures like communication, transport, electricity, and other vital utilities. "We have electric fencing for our livestock. How will we cope with all this; how will we survive." This combination of economic, social and psychological ties to their livelihood makes the farmers severely susceptible to damage and losses and increase their vulnerability, similar to that shown by Alexander (2000). Losses from catastrophic events are likely to have both economic and emotional consequences and may add to the vulnerability of the residents.

"If wet tephra accumulates on my roof my house will be ruined," said a gentleman in the village. The man was worried about damage of his house if the roof collapsed from the weight of the wet tephra.

In the town of Vík, both a young woman and a middleaged man saw opportunities after an eruption; they saw a window of opportunity as expressed by Alexander (2000). The opportunity was in the tourist industry, "Tourists will arrive in the village during an eruption and we do appreciate more tourism. We really need more tourists here so I would welcome an eruption."

Nevertheless, the residents perceived that visitors to the region were more vulnerable to volcanic hazards than them- selves. One of the villagers said, "If Katla erupts during the peak of the tourist season. I don't know if we can rescue the tourists and keep them safe."

It is obvious that the residents believe that people without local knowledge are more exposed to the natural hazard in this area (Morin et al., 2008; Bird et al., 2010). Tourists will be vulnerable in the area during an eruption and it is important to make information available to them about the hazard from Katla, especially on busy hiking trails in the highland during the summer.

Some villagers were concerned about severe coastal erosion in Vík. One woman expressed her worries when she said, "The sand on the coast is almost gone and it makes it easier for the tsunami to reach the houses down by the sea." Another woman was more optimistic, "Katla will improve the coastline and give shelter to the village." A middle-aged man in Vík did not think the hazard from Katla would do much damage in the village, but he stated, "We are worried about the coastal erosion since the coast is getting closer to the village. If we have an eruption, sediment from the jökulhlaup will increase down by the coast and we will have sand accumulating on the beach and the erosion will stop."

From this point-of-view, an eruption may increase their resilience in the long run as the coastal erosion and storm surges will decrease. However, if the tsunami comes in the wake of an eruption, the inhabitants may suffer since the village is so close to the sea and the tsunami may damage coastal structures.

The landscape in Álftaver is flat but some of the inhabitants were convinced that the rootless cones on the outskirt of the area (Figs. 1 and 4) will protect the community from the outburst flood.

One of the women in Álftaver believed that the water will surge down the outwash plain fast and furiously but on the outskirt of the community the sand has piled up against the rootless cones. The vegetation, the Leymus arenarius, and the rootless cones will protect the community by diverting the flood away from the community. Other areas will be more at risk. Another woman in Álftaver was not convinced about the protection by the rootless cones, "There is nothing that stops this flood; we cannot rely on some mounds of sands or rootless cones to protect our environment even though they have been of some protection in the past."

The protection by the rootless cones (Figs. 1 and 4) is embedded in the consciousness of people in Álftaver, an experience passed on through generations living in the area (Jóhannesdóttir, 2005). Nevertheless, because the outwash plain is higher at present than prior to the last eruption (Thordarson and Höskuldsson, 2002) the residents in Álftaver are more vulnerable to flood risk.

A farmer in Álftaver knew from the past that areas outside Álftaver were at great risk to tephra fall. He was convinced that they would not have much tephra fall in Álftaver since they hardly ever had northwesterly wind on the area. Another farmer said, "During the summer we have southerly 
and easterly wind, at least it feels like it when you are working in the fields." This indication about the weather condition in the area may increase their resilience during an eruption.

Much time and effort has gone into restoring vegetation on Mýrdalssandur plain (Fig. 2). Residents in both communities gave detailed information on the sandstorms that increased severely after the 1918 jökulhlaup because of the sediment that was deposited on Mýrdalssandur plain. The sandstorms damaged their houses, cars and other equipments. One woman in Álftaver said, "Previously Mýrdalssandur was a complete desert but gradually it has become green and plants are thriving. An eruption will ruin the vegetation and we would have to start all over again." Environmental degradation following an eruption will make the residents more vulnerable and even lead to economic collapse (Smith, 2004).

Clearly, the residents are aware of the risk as one of the farmers said, "You know "she" (Katla) is there and I monitor "her" (the volcano) every day when I am working in the field, Katla is there and I am here and I just can't worry all the time." One farmer said that he had learnt from those who experienced the 1918 eruption, that when the glacier's surface is level with two certain peaks seen from her farm it would be time to prepare an evacuation. This inherited knowledge taught her how to recognise physical indicators that in turn may increase her resilience (Morin et al., 2008).

\subsection{Emergency, preparedness plans and evacuation}

To increase the resilience of the residents, a mutual understanding, a dialogue and collaboration is essential between all stakeholders related to the disaster's prevention, preparedness, response and recovery. The local district commissioner is in charge of operations in the event of an eruption in the two communities. His perception to such a collaboration was the following, "The scientists monitor all the equipment around the volcano and they will let me know if there are indications of an activity in Katla. During an eruption, I will be in charge and manage the response, the evacuation plans and the rescue team will assist me. I am confident that we can start to evacuate before the eruption starts. We hope we will get a minimum of twelve hours to evacuate at least if the scientific calculation and monitoring is accurate." His assumptions are early warning signs and a long warning time.

The local district commissioner further stated that the government was always concerned about an eruption. "On the other hand, funding was always a problem, but once an eruption has started, funding is easier; this was the case in an eruption in Vatnajökull glacier in 1996." This indicates the fact that the governmental approach to disaster management has put more effort in responding to various hazardous events than on prevention and preparedness (e.g. Kjartansson, 2008). By increasing funding and education of hazard preparedness and prevention, the local population may become more resilient during disasters.
The mayor of Vík had a different perspective to the evacuation procedure than the local district commissioner. He was satisfied with the evacuation plans and had confidence in the residents, "They know what to do and some residents in the village are involved in evacuation procedures. We will make sure that all residents will be contacted. Once we know that the eruption has started, we can swiftly evacuate the village."

Some discussions were about new residents in Vík and how they were informed about the emergency and evacuation plans and if they knew what to do. The mayor said, "New residents in Vik are often obsessed with Katla but they soon realize that everything is under control."

Decision making and risk is a complex process and risk perception and trust plays a crucial role in that procedure. If people perceive the risk as real, they will act accordingly (Slovic, 2000), which is not necessarily the correct action. Thus, risk communication and education is vital.

The discrepancies in the perception of the local district commissioner and the residents about the evacuation process indicate a lack of collaboration between the emergency managers and the public. In Álftaver, the residents did not agree with the local district commissioner about the evacuation procedure and some even said they would not evacuate. They referred to the fact that past generations had survived the eruption and they were convinced that it would apply to them as well. In contrast, many villagers believed that an eruption would bring about enormous difficulties in Álftaver. Nevertheless, participants had not made any special survival kits or preparedness plans of their own. In some cases, the participants had put a disaster information poster, distributed by the authorities as a checklist during eruptions, somewhere away in storage.

The collaboration between scientists, officials in charge of risk and emergency management, and the local population seems limited, and it is likely to create conflict during the efficiency of the evacuation process ${ }^{1}$. In Álftaver people were concerned about risk communication during an eruption. One resident stated, "We are supposed to get information once the eruption starts but the nature of farming is such that we work outdoors in the fields and I somehow wonder if we can be reached. That was our experience in an evacuation exercise 10 years ago." They also found the evacuation process complex and confusing. An older farmer was sceptical of the evacuation plans, "The plans will collapse if there is a power failure and what if our cars will not start. I don't think helicopters will rescue us if the tephra and ash fall has begun."

In Vík, the participants knew they had to evacuate to the hills north of the village if a tsunami followed an eruption.

\footnotetext{
${ }^{1}$ In August 2008 scientists investigating the hazard from Katla came together to exchange ideas with stakeholders, emergency managers, officials and the general public in Vík in order to share information and give an update on scientific research on Katla, emergency plans and public participation.
} 
However, some of the women were concerned about their children, "If the children are in school or playing by the coast I will not evacuate unless I know the children are safe."

An evacuation exercise is practised every year in the village school and a young woman described her trauma that she experienced after an exercise when she was a child, "I had nightmares and I dreamt of the tsunami and there was water everywhere and it covered the whole village. I know my brother and some kids in my class also had similar experience, but as an adult I never worry." It is important to know the perception of children when presenting hazard knowledge (e.g. Ronan et al., 2001; Johnston et al., 2005).

As mentioned in this study, evacuation exercises have been few and only for the communities east and south of Katla. In 2006, a large-scale live evacuation exercise was conducted for the whole Katla area including a recently identified volcanic zone to the west of the glacier. This study on risk perception, vulnerability and evacuation provided the planners of the exercise with valuable information about residents' potential response during the exercise (V. Reynisson, personal communications, 2007). In 2006, changes were made in the disaster management in Vík (Act 46/2006) and the evacuation plans were improved in order to meet the residents' requirements and needs.

\section{Conclusions and recommendations}

The participants' risk perception of social, cultural and economic elements clearly indicates that the communities are vulnerable to Katla eruption. This is especially true for people in Álftaver, as they live in the direct path of the jökulhlaup and, therefore, are exposed to the threat. An eruption may lead to a great loss for the local community. However, their strong cultural and social cohesion and local knowledge may increase resilience during an eruption. Their isolation from the rest of the district may force them to join forces and stand together. Strong oral tradition and storytelling serves as a regular reminder of the hazardous environment they live in. Their cultural framework reflects the social structure they live in and gives rise to their feelings that they will be safe like their forefathers before them. They use a normalizing defensive mechanism to make this possible. They have strong awareness and their risk perception is high. Their lack of mitigation, prevention and preparedness may be due to the fact that the hazardous event has not happened during their lifetime. They feel that other recent natural hazards outside their region are more hazardous. In Vík, the residents are less vulnerable, they have a longer warning period and feel they are not directly exposed to the threat. Nevertheless, if the village is hit by a tsunami, they will be at risk. From an economic perspective, the participants in the two communities look differently at the aftermath of an eruption. While residents in Álftaver perceive an eruption as a destructive and negative force to their community, the benefit of an eruption according to some residents in Vík is increased tourism and improved coastal development. Trust in the official evacuation plans was limited in the farming community and the residents found the evacuation process confusing and some had forgotten the basic evacuation procedure. The residents have to rely on a fast flow of information and proper transportation away from the hazardous area and they felt insecure about the evacuation process. To increase their resilience, it is recommended that the residents' role in the evacuation plan is increased in order to increase their responsibility, rather than relying on rescue from outside the area. In Vík the participants were quite confident about the evacuation and did not think they were at risk. The district commissioner was not collaborating with all concerned and did not have a holistic view on the disaster management. The scientists and the administrators have not communicated the risk and warning to the general public in a way that the residents could relate to. Increased hazard information has to be disseminated within the communities by the local civil protection authorities.

It is apparent that risk perception studies will add important knowledge to emergency management. They can give the emergency managers a better understanding of people's attitude towards the risk and predict public response. Furthermore, they can be used to make available information on how to increase awareness and facilitate educational programs. Understanding risk perception and vulnerability may also be useful to prevent conflicts during emergency situations. Additionally, they can be used in the risk communication process.

Findings from vulnerability research can be used to support residents in accepting their vulnerability as it can increase warning effectiveness and improve their mitigation and preparedness. It is important to apply cross disciplinary approaches when assessing hazards and risks. Scientists, emergency managers, the people at risk and the media should collaborate in order to create a better understanding and when an eruption is forecast, the risk communication must be presented in terms that people understand and are more likely to react according to the plans.

Acknowledgements. We thank all the participants in Álftaver and Vík for their willingness to participate in the investigation. Especially we thank Marin I. Kardjilov for the map production and the University of Iceland Assistance Fund for economic support. This article benefited from valuable comments from Dale Dominey-Howes and an anonymous reviewer.

Edited by: J. Birkmann

Reviewed by: D. Dominey-Howes and another anonymous referee 


\section{References}

Alexander, D.: Confronting Catastrophe: New perspectives on Natural Disasters, Terra Publishing, Herfordshire, England, 2000.

Alexander, D.: Making research on geological hazards relevant to stakeholders needs, Quatern. Int., 171-172, 186-192, 2007.

Balso, M. and Lewis, A.: A Guide to Social Research, International Thompson Publishing. Scarborough, Ontario, Canada, 1997.

Bird, D. and Dominey-Howes, D.: Tsunami risk mitigation and the issue of public awareness, Australian Journal of Emergency Management, 21, 29-35, 2006.

Bird, D., Gisladottir, G., and Dominey-Howes, D.: Volcanic risk and tourism in southern Iceland: Implication for hazard, risk and emergency response education and training, J. Volcanol. Geoth. Res., 189, 33-48, 2010.

Bird, D. K., Gisladottir, G., and Dominey-Howes, D.: Resident perception of volcanic hazards and evacuation procedures, Nat. Hazards Earth Syst. Sci., 9, 251-266, 2009,

http://www.nat-hazards-earth-syst-sci.net/9/251/2009/.

Bjarnason, V.: Á flótta undan Kötluhlaupi, Dynskógar, 3, 149-173, 1986.

Björnsson, H.: Subglacial lakes and jökulhlaups in Iceland, Global Planet. Change, 35, 255-271, 2002.

Björnsson, H., Pálsson, F., and Guðmundsson, M. T.: Surface and bedrock topography of the Mýrdalsjökull ice cap, Iceland: The Katla caldera, eruption sites and routes of Jökulhlaups, Jökull, the Icelandic Journal of Earth Sciences, 49, 29-46, 2000.

Blaikie, P., Cannon, T., Davis, I., and Wisner, B.: At risk: Natural hazard, people's vulnerability and disasters, Routledge, London, UK, 1994.

Boholm, Å.: Comparative studies of risk perception: a review of twenty years of research, J. Risk Res., 1(2), 135-163, 1998.

Crichton, D.: The risk triangle, in: Natural Disaster Management, Tudor Ross, London, 102-103, 1999.

Deyle, R., French, S., Olshansky, R., and Paterson, R.: Hazard Assessment: The Factual Basis for Planning and Mitigation, in: Cooperating with Nature edited by: Burby, R., National Academy Press, Joseph Henry Press, Washington, DC, 1998.

Einarsson, P. and Brandsdóttir, B.: Earthquakes in the Mýrdalsjökull area, Iceland, 1978-1985: seasonal correlation and connection with volcanoes, Jökull, the Icelandic Journal of Earth Sciences, 49, 49-73, 2000.

Fischoff, B., Slovic, P., Lichtenstein, S., Read, S., and Combs, B.: How safe is safe enough; a psychometric study of attitudes toward technological risks and beliefs, Policy Study, 9, 127-152, 1978.

Friðfinnsson, B.: Almannavarnir og áfallapol íslensk samfélags, Dóms- og kirkjumálaráđuneytið, Málping um framtíðarskipulag almannavarna- og björgunarmála, 8 March 2005.

Gísladóttir, G.: Örnefni í Álftaveri, Verkfræði- og raunvísindadeild, Háskóli Íslands, B.Sc. thesis in Geography, unpublished, 1980.

Gísladóttir, G. and Margrétardóttir, E.: Áhrif uppgræðslu á sandfok og lokun pjóðvegar 1 um Mýrdalssand, (RH-01-2004): Reykjavík, Raunvísindastofnun Háskólans, 2004.

Gregg, C. E., Houghton, B., Johnston, D. M., Paton, D., and Swanson, D. A.: The perception of volcanic risk in Kona communities from Mauna Loa and Hualalai volcanoes Hawaii, J. Volcanol. Geoth. Res., 130(3-4), 179-196, 2004.
Guðjónsson, G. and Gíslason, E.: Vegetation map of Iceland, 1:500 000, General Overview, 1st. edn., Icelandic Institute of Natural History, Reykjavík, 1998.

Guðmundsson, M. T. and Högnadóttir, Th.: Yfirlit yfir hættu vegna eldgos og hlaupa frá vesturhluta Mýrdalsjökuls og Eyjafjallajökli, in: Hættumat vegna eldgosa og hlaupa frá vestanverðum Mýrdalsjökli and Eyjafjallajökli edited by: Guðmundsson, M. T. and Gylfason, A., Ríkislögreglustjóri, Háskólaútgáfa, University Press, Reykjavík, 2005.

Guðmundsson, M. T., Högnadóttir, Th., Kristinsson, A. B., and Guðbjörnsson, S.: Geothermal activity in the subglacial Katla caldera, Iceland, 1999-2005, studied with radar altimetry, Ann. Glaciol., 45, 66-72, 2007.

Guðmundsson, M. T., Larsen, G., Höskuldsson, A., and Gylfason A.: Volcanic hazards in Iceland, Jökull, The Icelandic Journal of Earth Sciences, 58, 251-267, 2008.

Hargreaves, A.: Building Communities of Place; Habitual movement around significant places, Journal of Housing and the Built Environment, 9, 49-65, 2004.

Haynes, K., Barclay, J., Pidgeon, N.: Whose reality counts?; Factors affecting the perception of volcanic risk, J. Volcanol. Geoth. Res., 172, 259-272, 2008.

Ísaksson, G., Viggósson, G., Jóhannesson, H., and Pálsson, S.: The beach in front of Vík, Second International Coastal Symposium, Höfn, Iceland, 2005.

Johnston, D., Paton, D., Crawford, G. L., Ronan, K., Houghton, B., and Bürgelt, P.: Measuring Tsunami Preparedness in Coastal Washington, United States, Nat. Hazards, 35, 173-184, 2005.

Jóhannesdóttir, G.: "Við tölum aldrei um Kötlu hér”. Mat íbúa á hættu vegna Kötlugoss, M.Sc. thesis in Environmental Sciences, Department of Geology and Geography, University of Iceland, unpublished, 2005.

Jóhannsson, G.: Kötlugosið 1918. Frásagnir úr Vík og Heiðardal í Mýrdal, Hjörleifshöfða, Skaftártungu, Álftaveri, Meðallandi og Síðu. Reykjavík, Bókaverslun Ársæls Árnasonar, 1919.

Jóhannesson, H., Jakobsson, S.P., Saemundsson, K.: Geological map of Iceland, sheet 6, South-Iceland, 3rd edn., Icelandic Museum of Natural History and Iceland Geodetic Survey, Reykjavík, 1990.

Jónsson, H.: The history of the Civil Protection of Iceland, Reykjavík, Iceland, unpublished manuscript, 2003.

Kasperson, R., Renn, O., Slovic, P., Brown, H., Emel, J., Goble, R., Kasperson, J., and Ratick, S.: The Social Ampification of Risk, in: A Conceptual Model, edited by: Cutter, S., Environmental Risks and Hazard, Upper Saddle River Prentice Hall, 1994.

Kjartansson, Ó. H.: Stjórnsýsla almannavarna. The Civil Protection Administration, MPA thesis, University of Iceland, unpublished, 2008.

Larsen, G.: Holocene eruption within the Katla volcanic system south Iceland; Characteristics and environmental impact, The Icelandic Journal of Earth Sciences, 49, 1-27, 2000.

Lindell, M. K.: Perceived characteristics of environmental hazards, International Journal of Mass Emergencies and Disasters, 12(3), 303-326, 1994.

Lög um almannavarnir: Act on Civil Protection 94, Althingi, 1962. Lög um almannavarnir: Act on Civil Protection 82, Althingi, 2008. Lögreglulög: Act 90/1996. Act on Police 90, 1996 and 46/2006, Althingi, 2008.

Mileti, D. and O'Brien, P.: Warning during disasters; normalising 
communicational risk, Soc. Probl., 39(1), 40-57, 1992.

Mileti, D.: Human Adjustment to the Risk of Environmental Extremes, in: Environmental Risks and Hazard, edited by: Cutter, S., Upper Saddle River Prentice Hall, 1994.

Mileti, D. and Peek, L.: The social psychology of public response to warning of a nuclear power plant accident, J. Hazard. Mater., 75(2-3), 181-194, 2000.

Miller, T. G.: Environmental Science. Working with the Earth.Wadsworth Publishing Company, A Division of Wadsworth Inc., Belmont California, 1995.

Morin, J., De Coster, B., Paris, R., Flohic, F., Le Floch, D., and Lavigne, F.: Tsunami-resilient communities' development in Indonesia through educative actions: Lessons from the 26 December 2004 tsunami. Disaster Prevention and Management: An International Journal, 17(3), 430-446, 2008.

Otway, H.: Public Wisdom, Expert Fallibility: Toward a Conceptual Theory of Risk, in: Social Theories of Risk, edited by: Krimsky, S. and Golding, D., Praeger, London, UK, 1992.

Pidgeon, N., Hood, C., Turner, B., and Gibson, R.: Risk Perception: Risk: Analysis, Perception and Management, London: The Royal Society, 1992.

Reynisson, V.: The department manager for the Icelandic Civil Protection, a personal communication, 5 April 2007.

Ríkislögreglustjóri, Almannavarnadeild: Katla - Austur hluti, available at: http://www.almannavarnir.is/default.asp?cat_id= 193 (last access: 5 July 2008), 2008.

Ronan, K. R., Johnston, D. M., Daly, M., and Fairley, R.: School children's risk perception and preparedness: A hazard education survey, Australian Journal of Disaster and Trauma Studies, 1, ISSN:1174-4707, available at: http://www.massey.ac.nz/ trauma/issues/2001-1/ronan.htm(last access: 19 April 2008, 2001.

Safn til sögu Íslands IV: Copenhagen and Reykjavík, Hiðíslenska bókmenntafélag, 186-294, 1907-1915.
SEMA (Swedish Emergency Management Agency): Risk and vulnerability analyses, A guide of governmental agencies, 2008.

Sjöberg, L.: Factors in Risk Perception, Risk Anal., 20(1), 1-11, 2000.

Slovic, P., Fischoff, B., Lichtenstein, S.: Accident probabilities and seat belt usage: A psychological perspective, Accident Anal. Prev., 10(4), 281-285, 1978.

Slovic, P.: The Perception of Risk, London, Earth Scan Publication, 2000.

Slovic, P., Finucane, M. L., Peters, E., and MacGregor, D. G.: Risk Analysis and Risk as a Feeling: Some thought about Affect, Reason, Risk and Rationality, Risk Anal., 24(2), 311-3221, 2004.

Smit, B. and Wandel, J.: Adaptation, adaptive capacity and vulnerability. Global Environ. Chang., 16(3), 282-292, 2006.

Smith, K: Environmental Hazards. Assessing Risk and Reducing Disaster, Routledge, New York, 2004.

Sturkell, E., Einarsson, P., Sigmundsson, F., Geirsson, H., Ólafsson, H., Pedersen, R., de Zeeuw-van Dalfsen, E., Linde, A. T., Sacks, S. I., and Stefánsson, R.: Volcanic geodesy and magma dynamics in Iceland, J. Volcanol. Geoth. Res., 150, 14-34, 2006.

Sveinsson, G.: Skýrsla um Kötlugosið 1918 og afleiðingar pess, in: Rit um jarðelda á Íslandi, edited by: Loftsson, M., Reykjavík, Skúli Magnússon, 140-194, 1930.

Thordarson, T. and Höskuldsson, A.: The central south, in: Iceland Classic Geology in Europe 3, edited by: Thordarson, T. and Höskuldsson, A., Harpenden, England: Terra Publishing, 97121, 2002.

Thordarson, T. and Larsen, G.: Volcanism in Iceland in historic time: Volcano types, eruption, styles and eruptive history, J. Geodyn., 43, 118-152, 2007.

Tómasson, H.: The jökulhlaup from Katla in 1918, Ann. Glaciol., 22, 249-254, 1996. 